\title{
Phytoprotection
}

\section{Virus Resistant Transgenic Sweet Potato with the CP Gene : Current Challenge and Perspective of its Use}

\author{
Masamichi Nishiguchi et Masaki Mori
}

Volume 79, numéro 4, 1998

OECD Workshop - Sustainable Pest Management, Safe Utilization of New Organisms in Biological Control. Montréal, Québec, Canada. September 27-30, 1998.

Atelier de l'OCDE - Gestion durable des ennemis des cultures, Utilisation sécuritaire de nouveaux organismes de lutte biologique. Montréal, Québec, Canada. 27-30 Septembre 1998.

URI : https://id.erudit.org/iderudit/706167ar

DOI : https://doi.org/10.7202/706167ar

Aller au sommaire du numéro

\section{Éditeur(s)}

Société de protection des plantes du Québec (SPPQ)l

ISSN

0031-9511 (imprimé)

1710-1603 (numérique)

Découvrir la revue

Citer cet article

Nishiguchi, M. \& Mori, M. (1998). Virus Resistant Transgenic Sweet Potato with the CP Gene : Current Challenge and Perspective of its Use. Phytoprotection, 79(4), 112-116. https://doi.org/10.7202/706167ar

\section{Résumé de l'article}

Virus diseases of sweet potato are very prevalent and often seriously damage to the plants. Especially sweet potato feathery mottle virus severe strain (SPFMV-S) causes russet crack disease in Japan. In order to confer virus resistance against SPFMV using current biotechnology, we have produced transgenic sweet potato with an expression vector plasmid harboring the coat protein (CP) gene as well as hygromycin phosphotransferase gene (HPT). The plasmid was introduced into mesophyll protoplasts of a sweet potato breeding line, Chikei 682-11 (Ipomoea batatas L.(Lam.)) by electroporation. Protoplatsts were further cultured in the presence of hygromycin. Some of the hygromycin resistant calli were grown to form adventitious shoots. Southern blot analysis with $\mathrm{CP}$ and HPT genes showed that these genes were integrated into the chromosomes in four lines. Expression of the CP gene was confirmed by Northern and dot immuno blot analyses. Each line was grafted with the SPFMV-S infected morning glory (I. nill) to reveal any virus resistance conferred. After three months from the graft-inoculation, these transgenic plants were used for ELISA test in order to know any virus infection. There was no significant differences of ELISA values between the inoculated-transgenic and the non inoculated-virus free plants, suggesting that these transgenic plants were not infected with the virus. They produced storage roots, from which the young shoots were again found to be virus-free by ELISA. We concluded that these transgenic plants were highly resistant to the virus. Concerns about the releasing transgenic plants that contain genes from other species include the potential weediness of the plants as well as the potential flow of the transgenic genes to other plants through normal outcrossing. Usually sweet potato is a vegetatively propagated and hardly flowers during growing seasons in Japan. Under these circumstances it might be safe to release these transgenic plants. One concern unique to virus resistant transgenic plants is that a viral sequence from transgene may be potentially incorporated by RNA recombination into a virus that may infect the transgenic plants. There is no useful information available on the occurrence of recombinant virus under the very high level of resistance. From the point; whether or not the frequency of recombination in the transgenic plants greater than that in plants with two or more viruses, it would be at least much lower in these highly virus resistant transgenic plants.
Ce document est protégé par la loi sur le droit d'auteur. L’utilisation des services d’Érudit (y compris la reproduction) est assujettie à sa politique d'utilisation que vous pouvez consulter en ligne.

https://apropos.erudit.org/fr/usagers/politique-dutilisation/ 


\title{
Virus Resistant Transgenic Sweet Potato with the CP Gene: Current Challenge and Perspective of its Use
}

\author{
Masamichi Nishiguchi, Masaki Mori \\ National Institute of Agrobiological Resources, 2-1-2 Kan-nondai, Tsukuba, \\ Ibaraki 305-8602, Japan
}

\author{
Yoshihiro Okada and Tatsuro Murata \\ Kyushu Tokai University, Choyo, Aso-gun, Kumamoto 862-8652, Japan
}

\author{
Takashi Kimura, Jun-ichi Sakai, and Kaoru Hanada \\ Kyushu National Agricultural Experiment Station, Nishigoushi, Kikuchi-gun, \\ Kumamoto 861-1192, Japan
}

\section{Chikara Miyazaki, Akira Saito}

Nagasaki Laboratory, Japan Science and Technology Cooperation, 2-1303-8, Ikeda, Ohmura, Nagasaki 856-0026, Japan,

\section{ABSTRACT}

Virus diseases of sweet potato are very prevalent and often seriously damage to the plants. Especially sweet potato feathery mottle virus severe strain (SPFMV-S) causes russet crack disease in Japan. In order to confer virus resistance against SPFMV using current biotechnology, we have produced transgenic sweet potato with an expression vector plasmid harboring the coat protein (CP) gene as well as hygromycin phosphotransferase gene (HPT). The plasmid was introduced into mesophyll protoplasts of a sweet potato breeding line, Chikei 682-11 (Ipomoea batatas L.(Lam.)) by electroporation. Protoplatsts were further cultured in the presence of hygromycin. Some of the hygromycin resistant calli were grown to form adventitious shoots. Southern blot analysis with CP and HPT genes showed that these genes were integrated into the chromosomes in four lines. Expression of the CP gene was confirmed by
\end{abstract}

Northern and dot immuno blot analyses. Each line was grafted with the SPFMV-S infected morning glory (I. nill) to reveal any virus resistance conferred. After three months from the graft-inoculation, these transgenic plants were used for ELISA test in order to know any virus infection. There was no significant differences of ELISA values between the inoculated-transgenic and the non inoculated-virus free plants, suggesting that these transgenic plants were not infected with the virus. They produced storage roots, from which the young shoots were again found to be virus-free by ELISA. We concluded that these transgenic plants were highly resistant to the virus.

Concerns about the releasing transgenic plants that contain genes from other species include the potential weediness of the plants as well as the potential flow of the transgenic genes to other plants through normal outcrossing. Usually sweet potato is a vegetatively propagated and hardly flowers 
during growing seasons in Japan. Under these circumstances it might be safe to release these transgenic plants. One concern unique to virus resistant transgenic plants is that a viral sequence from transgene may be potentially incorporated by RNA recombination into a virus that may infect the transgenic plants. There is no useful information available on the occurrence of recombinant virus under the very high level of resistance. From the point; whether or not the frequency of recombination in the transgenic plants greater than that in plants with two or more viruses, it would be at least much lower in these highly virus resistant transgenic plants.

\section{INTRODUCTION}

Sweet potato is one of the most important crops in the world, especially in tropical, sub-tropical and temperate zones. It has been considered attractive as a natural health food because of its high energy, rich carbohydrates, dietary fiber, vitamin and mineral content (Hill et al., 1992). Sweet potato has been shown to support more people per unit square than any other crops. On the other hand, virus diseases cause serious economic losses on sweet potato, especially russet crack disease (Clark and Moyer, 1988) or "obizyo-sohi" disease in Japanese (Usugi et al., 1994). This disease is caused by sweet potato feathery mottle potyvirus (SPFMV) russet crack (RC) strain or severe strain(S). To circumvent the damages by the virus, virus free plants are used partly on commercial base and in some prefectures they have their own facilities for supplying their farmers with virus free plants in Japan. However they are reinfected with the virus in a couple of years. A step towards molecular breeding of virus resistant sweet potato, we have cloned and sequenced the causal virus, SPFMV-S (Sakai et al., 1997) and produced transgenic sweet potato expressing the CP gene resistant to the virus (Okada et al., submitted). In the present paper, we report the virus resistance in the transgenic sweet potato and discuss the perspective for their safe use in the field.

\section{RESULTS}

Sweet potato feathery mottle potyvirus severe strain (SPFMV-S) has been selected for the experiments. SPFMV is found almost everywhere sweet potatoes are grown in the world. The symptoms vary widely; very faint chlorotic patterns along the midrib, chlorotic spots, some times purple ring spot in the later stage of growth and russet crack on storage roots. In Japan at least four strains have been reported including severe (S), ordinary (O), Tokushima (T) and F strains. SPFMV-S is a causal agent of russet crack disease in Japan (Usugi et al., 1994).

Then the CP gene of SPFMV-S was inserted between CaMV35S promoter and nos terminator and the resultant plasmid with a hygromycin resistant gene as a selectable marker was used to transform sweet potato protoplasts using electroporation. The system for regeneration from protoplasts has been established for very few varieties of sweet potato (Murata et al., 1994). Electroporated protoplasts were cultured in the presence of hygromycin. Calli resistant to hygromycin were further incubated to produce shoots. Nineteen plants from 7 lines were obtained from one variety, Chikei 682-11.

The genomic Southern hybridization showed that 4 out of 19 regenerated plants contained the CP gene of SPFMV$\mathrm{S}$. Those include transgenic plants, EP 200-1-1, 200-2-1, 220-1-1 and 220-1-2. According to the banding pattern of the Southern blotting, the copy number of the CP gene in EP 200-2-1 was more than three and one copy in the other three. It might be possible that both EP 220-1-1 and 220-2-1 were derived from the same transformation event because the banding pattern was the same each other. In the case of EP 200-1-1, very faint bands besides the major ones were observed at the same positions as those in EP 200-1-2. This indicates that the two lines might have be derived from the same transformation events but that EP 200-1-1 grew into a chimera tissue in the course of regeneration. 
Northern blot analysis showed that the two types of the CP transcripts of sizes (approximately 1.3 and $1.4 \mathrm{~kb}$ ) were detected in all of the transformants. The two different lengths of the transcripts were not checked in more detail. The transformants, EP 220-1-1 and EP 220-2-1, had one larger transcript of $2.4 \mathrm{~kb}$ besides the two transcripts. It may possible that these larger transcripts were derived from the insert on other loci. Western blot analysis showed that only one line (EP 220-1-1) had the signal corresponding to SPFMV$\mathrm{S} C P$ and that the CP of all others were under the level of detection. However the dot-immunobinding assay showed that the specific spots were found in all transgenic plants while the control plants had no positive reaction.

Protection of transgenic sweet potato against SPFMV-S infections was investigated by graft-inoculation using SPFMV-S infected morning glory (Ipomoea nill) because it was very difficult to manually inoculate sweet potato with the virus. Three months later the virus titer in the plants was checked using ELISA. As a result, almost the complete resistance was shown with all of four lines of transformants. These plants were further cultivated to produce storage roots. The young shoots from the roots were found to be virus free by ELISA.

The transgenic plants were compared to the non transgenic regenerated plants in some morphological and biological characters including pole climbing, internode length, nodal root, leaf shape, apical leaf color, leaf and corolla color, corolla size and pollen fertility. There seemed no significant different traits in them compared to the non transgenic regenerated plants.

\section{DISCUSSION AND PERSPECTIVE}

Russet crack disease seriously damages to sweet potato, especially sweet potato varieties for fresh market in Japan. Only measure for its control is to remove the diseased plants. Thus it had been favored to produce virus re- sistant lines using either conventional or unconventional breeding method. However there is no information available on resistant gene(s) against SPFMV. Thus a transgenic approach was taken. As a result highly resistant transgenic sweet potato have been produced.

SPFMV is transmitted by aphids under natural conditions. Since manual inoculation is almost impossible for sweet potato plants, we used graft-inoculation of the plants with the virus. Generally graft-inoculation is more efficient than aphid inoculation. If aphids are used for the transgenic plants for assaying virus resistance, higher resistance could be obtained. Further experiments in the fields are needed.

All of four transgenic lines showed high resistance against the virus. Since the CP mRNA as well as CP was detected in all of them, the resistance is thought to be protein-mediated.

In Japan sweet potato growers usually spend the substantial costs for virus free plants. Thus the use of virus resistant transgenic plants would contribute considerably to lowering the costs for sweet potato production. It could be also greatly beneficial to growers in terms of the increasing yields in better quality.

Sweet potato is vegetatively propagated. It hardly flowers and is an annual crop here. It can not grow in winter. If the transgenic plants are released into the field, there would be no potentiality of their weediness under natural conditions. There would be also no potential flow of the transgene into other plants by crossing because of no flowering of sweet potato here From these points of view, it would be safer to use sweet potato here than other crops which can usually produce seeds under natural conditions.

The transgenic plants were found to contain the detectable level of CP mRNA. One may presume that RNA recombination may occur between transgene mRNA and viral RNA, which infects them, as suggested by Greene and Allison (1993). However they later showed that no recombinant virus was detected in the plants expressing the $\mathrm{CP}$ with 
deletions in the $3^{\prime}$ untranslated region (UTR), implying the reduced possibility of recombination by omitting or disrupting the $3^{\prime}$ UTR in the transgene (Greene and Allison, 1996). Our plasmid construct contained the CP gene and 3' UTR with poly A tract (Okada et al., submitted). In this point it would be more favorable to remove the 3' UTR from the construct.

Under highly virus resistant conditions, there are no useful information available on the potential occurrence of recombination between viral sequence from transgene and a viral genome. It needs to investigate whether or not recombinant RNA virus occur and overcome the resistance in these transgenic plants. These transgenic plants could be a good source for this kind of experiment. From the point; whether or not the frequency of recombination in the transgenic plants greater than that in plants with two or more viruses (Tepfer, 1993), it would be at least much lower in these highly virus resistant plants.

In Africa, SPFMV alone is not important in terms of symptoms. However the mixed infection with SPFMV and a whitefly transmitted sweet potato chlorotic stunt closterovirus (SPCSV) caused severe symptoms, called sweet potato virus disease (SPVD), on sweet potato (Gibson et al., 1998). The SPFMV resistant sweet potato would benefit growers there because SPCSV alone, causing a slight effect, may infect under such circumstances.

\section{ACKNOWLEDGMENTS}

This work was supported by "Integrated Research Program for the Use of Biotechnological Procedures for Plant Breeding" Grant-in-Aid from the Ministry of Agriculture, Forestry and Fisheries of Japan. The authors are grateful to Dr. K. Komaki, National Agricultural Research Center for his advise and comments.

\section{REFERENCES}

Clark, C. A. and Moyer, J. W. W.(1988). Compendium of sweet potato disease. APS press. pp74.

Gibson, R.W., Mpembe, I., Alicai, T., Carey, E.E., Mwanga, R.O., Seal, S.E. and Vetten, H.J. (1998) Symptoms, aetiology and serological analysis of sweet potato virus disease in Uganda. Plant Pathology 47: 95-102.

Greene, A.E. and Allison, R. (1994) Recombination between viral RNA and transgenic plant transcripts. Science 263: 1423-1425.

Greene, A.E. and Allison, R. (1996) Deletions in the $3^{\prime}$ untranslated region of cowpea chlorotic mottle virus transgene reduce recovery of recombinant viruses in the transgenic plants. Virology 225:231-234.

Hill, W.A., Bonsi, C.K. and Loretan, P. (1992). Sweetpotato research: current status and future needs. in Sweetpotato technology for the 21st century (Hill, W.A., Bonsi, C.K. and Loretan, P.A. eds.). Tuskegee University. $\mathrm{p}$ xvii-xxvi.

Murata, T. Fukuoka, H. and Kishimoto, M. (1994). Plant regeneration from mesophyll and cell suspension of sweet potato, Ipomoea batatas (L.) Lam.. Breeding Science 44:35-40.

Okada, Y., Saito, A., Kimura, T., Mori, M., Nishiguchi, M., Hanada, K., Sakai, J., Murata, T., Matsuda, Y., Fukuoka, H. Virus resistance in transgenic sweet potato (Ipomoea batatas L.(Lam.) expressing coat protein gene of sweet potato feathery mottle potyvirus severe strain. (submitted).

Sakai, J., Mori, M., Morishita, T., Tanaka, M., Hanada, K., Usugi, T., and Nishiguchi, M. (1997). Complete nucleotide sequence and genome organization of sweet potato feathery mottle virus (S strain) genomic RNA. the large coding region of the P1 gene. Archives of Virology 142:1553-1562.

Tepfer, M. (1993) Viral genes and transgenic plants. what are the potential environmental risks? Bio/Technology 11:11251132.

Usugi, T., Nakano, M., Shinkai, A. and Hayashi, T. (1994). A distinct strain of sweet potato feathery mottle virus which causes obizyo-sohi disease on fleshy roots of sweet potato in Japan Ann. Phytopathol. Soc. Japan. 60:545-554. 


\section{QUESTIONS FOR DISCUSSION}

1) Can high resistance against virus infection be obtained in these transgenic plants under natural conditions?

2) What is the situation of these transgenic plants in tropical regions where they develop flowers easily?

3) How about the possibility of recombinant RNA virus in these plants under the high resistant conditions? 